\title{
AFECTAREA OSTEOARTICULARĂ ÎN FIBROZA CHISTICĂ LA COPIL
}

\author{
Dana-Teodora Anton-Păduraru' ${ }^{1}$, Ana-Simona Drochioi ${ }^{1}$, Oana Teslariu', \\ Alina Murgu ${ }^{2}$, Ioana Cernescu ${ }^{3}$, Alexandra-Dana Ifrim ${ }^{4}$, \\ Laura Mihaela Trandafir ${ }^{1}$ \\ ${ }^{1}$ Clinica III Pediatrie, Universitatea de Medicină şi Farmacie „, Gr. T. Popa “, Iaşi \\ ${ }^{2}$ Clinica II Pediatrie, Universitatea de Medicină şi Farmacie ,, Gr.T. Popa “, Iaşi \\ ${ }^{3}$ Serviciul Radiologie, Spitalul de Urgență pentru Copii ,, Sf. Maria “, Iaşi \\ ${ }^{4}$ Universitatea de Medicină şi Farmacie ,, Gr. T. Popa “, Iaşi
}

\begin{abstract}
REZUMAT
Afectarea osteoarticulară din fibroza chistică (FC) este considerată o complicație comună a acestei patologii. Prevenția, recunoaşterea precoce şi tratamentul corect efectuat reprezintă strategiile cele mai eficiente pentru susținerea sănătății osoase la bolnavii cu fibroză chistică. Scopul prezentului studiu a fost reprezentat de evaluarea clinico-paraclinică a bolnavilor diagnosticați cu FC aflați în evidența Clinicii III Pediatrie din cadrul Spitalului Clinic de Urgență pentru Copii „Sf. Maria“ laşi care prezentau şi simptome de afectare osteoarticulară. Rezultatele studiului au condus la concluzia că tratamentul cu vitamina $\mathrm{D}$, calciu şi suplimente cu multiminerale asociat cu regim igieno-dietetic corespunzător şi cu tratamentul de fond al maladiei poate contribui semnificativ la îmbunătățirea stării de sănătate, determinând şi ameliorarea calității vieții. Totodată, lipsa complianței la tratament a pacienților sau familiilor acestora contribuie semnificativ la instalarea precoce a complicațiilor, inclusiv a celor osteoarticulare (chiar de la vârsta de 6 ani).
\end{abstract}

Cuvinte cheie: fibroză chistică, afectare osteoarticulară, copil

\section{INTRODUCERE}

Fibroza chistică (FC) sau mucoviscidoza reprezintă cea mai frecventă afecțiune monogenică autosomal recesivă a populației de origine caucaziană, caracterizată prin pleomorfism clinic şi evoluție cronică progresivă, potențial letală (5).

Afectarea osteo-articulară a fost descrisă pentru prima dată în anul 1979, iar în prezent este considerată o complicație comună, în care cantitatea şi calitatea mineralelor osoase este scăzută. Prevenția, recunoaşterea precoce şi tratamentul corect efectuat reprezintă strategiile cele mai eficiente pentru susținerea sănătății osoase la bolnavii cu FC (2).

\section{OBIECTIVELE STUDIULUI}

Identificarea, evaluarea clinică-paraclinică şi răspunsul la tratamentul specific al manifestărilor osteoarticulare care însoțesc fibroza chistică.

\section{MATERIAL ŞI METODĂ}

A fost efectuat un studiu retrospectiv, pe un lot de 43 de pacienți, cu vârsta între 2 zile şi 18 ani, diagnosticați cu FC în Clinica III Pediatrie - Spitalul Clinic de Urgență pentru Copii „Sf. Maria“, Iaşi.

Protocolul de studiu a cuprins:

- bilanțul criteriilor care a stat la baza diagnosticului de FC;

- anamneza, care a precizat: vârsta, sexul, indicii antropometrici - talia, greutatea;

- evoluția clinico-biologică rezultată din examenele de control;

- cauzele afectării osteoarticulare;

- simptomatologia clinică (severitatea malabsorbției, simptome respiratorii, semne de afectare osteoarticulară şi vârsta de debut);

- relaţia dintre manifestările osteo-articulare şi frecvența infecțiilor respiratorii. 
- explorarea afectării osoase: dozare calciu, fosfor, fosfataza alcalină, dozarea concentrației serice de 25-OH-vitamina $\mathrm{D}$, osteodensitometrie, radiografia oaselor lungi, coloanei vertebrale toracale sau a pumnului;

- explorări necesare excluderii altor tipuri de artrită;

- tratamentul efectuat (tratament de fond al FC, corticoterapie, antiinflamatorii, antalgice, vitamina D) şi aderența la acesta;

- evaluarea răspunsului la tratament printr-un program de dispensarizare;

- educaţia şi consilierea bolnavilor şi familiei.

\section{REZULTATE}

Repartiția pe grupe de vârstă a bolnavilor din lotul cercetat a arătat că majoritatea bolnavilor cu FC aveau vârsta cuprinsă între 9-18 ani (51\%) şi că numai $5 \%$ erau sugari. În privința repartiției pe sexe, am observat o frecvență mai mare a bolii la pacienții de sex masculin (67\%).

Manifestările osoase au fost prezente la 7 dintre cei 43 bolnavi, fiind reprezentate inițial de semne de rahitism, demineralizare osoasă care a progresat până la osteoporoză în stadii avansate. Totodată, au fost identificate defecte posturale de tipul cifozei dorsale, toracelui astenic, lordoză şi contracturi musculare dureroase, monoartrită/oligoartrită şi hipocratism digital - Tabelul 1.

TABELUL 1. Manifestările osteoarticulare în lotul studiat

\begin{tabular}{|l|c|c|}
\hline $\begin{array}{l}\text { Semne și simptome ale afectării } \\
\text { osteoarticulare }\end{array}$ & Număr cazuri & Procente \\
\hline Cifoscolioză & 5 & $12 \%$ \\
\hline Contracturi musculare dureroase & 5 & $12 \%$ \\
\hline Monoartrită & 1 & $2 \%$ \\
\hline Oligoartrită & 1 & $2 \%$ \\
\hline Parestezii ale membrelor & 3 & $8 \%$ \\
\hline Carii dentare & 6 & $15 \%$ \\
\hline Mătănii costale & 5 & $13 \%$ \\
\hline Stern în carenă & 3 & $8 \%$ \\
\hline Torace evazat la bază & 2 & $5 \%$ \\
\hline Micrognatism & 1 & $3 \%$ \\
\hline Dismorfie craniofacială & 2 & $5 \%$ \\
\hline
\end{tabular}

Manifestările articulare au variat de la artralgii uşoare ( 5 cazuri) la artrite ( 2 cazuri), de obicei cu distribuție simetrică ( 5 cazuri) care au interesat următoarele articulații: glezne -2 cazuri, genunchi 3 cazuri, pumn -1 caz, cot $-1 \mathrm{caz}$, metacarpofalangiene - 2 cazuri. Debutul a fost insidios, ca o durere surdă ( 5 cazuri) sau prin durere articulară episodică, simptomele recidivând odată cu deteriorarea funcției respiratorii ( 2 cazuri). În aceste 2 cazuri am observat înrăutățirea simptomatologiei în timpul exacerbărilor infecției pulmonare cu Pseudomonas aeruginosa.

Cinci pacienți din lotul studiat au prezentat hipocratism digital, semn caracteristic OAHP.

Manifestările osteoarticulare" au debutat după un interval de timp de la diagnosticul FC cuprins între 5 şi 10 ani.

Analiza statusului nutrițional a evidenţiat că 14 bolnavi prezentau diferite grade de distrofie (3 cazuri - distrofie gradul I, 5 cazuri - distrofie gradul II, 6 cazuri - distrofie gradul III), iar 23 cazuri - hipotrofie ponderală. Toți cei 7 bolnavi cu FC şi manifestări osteoarticulare prezentau afectarea statusului nutrițional, iar 4 dintre ei semne de malabsorbție severă.

Cauzele deficitului vitaminei D au fost malabsorbția, aportul insuficient şi expunerea insuficientă la soare.

TABELUL 2. Cauzele deficienței de vitamina $D$ în lotul studiat

\begin{tabular}{|l|c|c|}
\hline Cauza deficitului vitaminei D & Număr cazuri & Procente \\
\hline Malabsorbția & 4 & $45 \%$ \\
\hline Aport insuficient & 3 & $33 \%$ \\
\hline Expunere insuficientă la soare & 2 & $22 \%$ \\
\hline
\end{tabular}

Dozarea calciului, fosforului şi fosfatazei alcaline la toți bolnavii cu FC a evidențiat: hipocalcemie la $34 \%$ dintre bolnavi, hipofosforemie la $31 \%$ dintre bolnavi şi creşterea fosfatazei alcaline la $26 \%$ dintre bolnavi.

Nivelul vitaminei D s-a dozat la 29 dintre cei 43 de bolnavi studiaţi (nivelul este considerat optim dacă concentrația serică a $25-\mathrm{OH}$-vitaminei D este între 30-50 ng/mL) (Tabelul 3).

TABELUL 3. Valorile 25-OH vitaminei $D$ în lotul studiat

\begin{tabular}{|l|c|c|}
\hline Nivelul 25-OH vitamina D & Număr cazuri & Procente \\
\hline Sub $10 \mathrm{ng} / \mathrm{mL}$ & 1 & $3 \%$ \\
\hline $10-20 \mathrm{ng} / \mathrm{mL}$ & 8 & $28 \%$ \\
\hline $20-100 \mathrm{ng} / \mathrm{mL}$ & 20 & $69 \%$ \\
\hline
\end{tabular}

Măsurarea densităţii osoase s-a efectuat prin osteodensitometrie, aceasta fiind o metodă precisă pentru diagnosticarea osteoporozei, dar şi un estimator precis al riscului de fractură. Rezultatele lotului studiat sunt evidenţiate în Tabelul 4.

TABELUL 4. Modificările osteodensitometriei la lotul studiat

\begin{tabular}{|l|c|c|}
\hline Rezultat osteodensitometrie & Număr cazuri & Procente \\
\hline Normal & 10 & $56 \%$ \\
\hline $\begin{array}{l}\text { Osteopenie (scor Z cuprins } \\
\text { între -1 şi -2,5) }\end{array}$ & 6 & $33 \%$ \\
\hline Osteoporoză (scor Z z-2,5) & 3 & $11 \%$ \\
\hline
\end{tabular}


Toți cei 7 bolnavi cu afectare osteoarticulară au prezentat valori scăzute ale scorului Z: 4 bolnavi osteopenie, 3 bolnavi - osteoporoză. Cei 3 bolnavi cu osteoporoză au prezentat simptomatologie osteoarticulară mai severă, iar la bilanţul biologic valori mai crescute al fosfatazei alcaline şi mai scăzute ale calcemiei şi fosforemiei comparativ cu bolnavii $\mathrm{cu}$ osteopenie.

Modificările radiologice la lotul studiat sunt prezentate în Tabelul 5.

TABELUL 5. Modificările radiologice identificate în lotul studiat

\begin{tabular}{|l|c|c|}
\hline Modificare radiologică & Număr cazuri & Procente \\
\hline $\begin{array}{l}\text { Periostoza capetelor distale ale } \\
\text { oaselor lungi }\end{array}$ & 5 & $18 \%$ \\
\hline $\begin{array}{l}\text { Lărgirea metafizei oaselor lungi, } \\
\text { aspect dilatat, în cupă }\end{array}$ & 6 & $22 \%$ \\
\hline $\begin{array}{l}\text { Linie metafizară concavă cu } \\
\text { margine neregulată }\end{array}$ & 6 & $21 \%$ \\
\hline Spiculi laterali & 4 & $14 \%$ \\
\hline Întârziere în osificarea nucleilor & 4 & $14 \%$ \\
\hline Cifoza & 3 & $11 \%$ \\
\hline
\end{tabular}

Cele 2 cazuri cu artrită au prezentat modificări radiologice multiple: lărgirea metafizei oaselor lungi, aspect dilatat, în cupă, întârziere în osificarea nucleilor şi spiculi laterali. Am remarcat prezenţa modificărilor radiologice inclusiv la bolnavi cu FC aparent normali, fără manifestări clinice osteo-articulare evidente.

Tratamentul afectării osoase a vizat în primul rând corectarea malabsorbției şi malnutriției, administrarea suplimentelor cu vitamine, minerale şi oligoelemente. $(4,16,17)$

Tratamentul medicamentos a cuprins:

1. tratament de substituție cu enzime pancreatice $\left(\mathrm{Kreon}^{\mathrm{R}}\right)$.

2. tratamentul infecțiilor pulmonare conform antibiogramei.

3. tratamentul deficitului de vitamina $\mathrm{D}$, respectiv al rahitismului, osteopeniei sau osteoporozei prin:

- administrarea suplimentelor cu vitamina D, sub formă de picături/tablete conținând colecalciferol sau sub formă injectabilă la cei cu malabsorbție severă.

- administrarea suplimentelor pe bază de calciu în asociere cu vitamina D sau sub forma unor complexe de multiminerale $(\mathrm{Ca}+\mathrm{Mg}+\mathrm{Zn}+$ Vitamina D) $5-10 \mathrm{ml} \times 2-3$ ori pe zi.

Tratamentul OAHP la pacienții din lotul studiat a constat în repaus la pat, administrarea de antalgice şi antiinflamatorii nesteroidiene/steroidiene (Acetaminophen, Ibuprofen $20-40 \mathrm{mg} / \mathrm{kg} / \mathrm{zi}$, corticotera- pie, 7 zile) concomitent cu tratamentul suferinței respiratorii (18).

După stabilirea diagnosticului şi instituirea măsurilor terapeutice, evoluția pacienților cu afectare osteoarticulară din lotul studiat a fost următoarea:

- persistența unor grade variabile de osteopenie mergând până la osteoporoză severă în cazurile cu malabsorbție persistentă;

- acutizări ale AFC şi OAHP asociate cu deteriorarea funcției pulmonare într-un caz.

Totodată, s-a făcut şi profilaxia agravărilor şi recăderilor.

\section{DISCUȚII}

Artrita din FC a fost prima dată descrisă de Ansell şi Newman. Principalele tipuri de artrită care apar în FC sunt artropatia din FC (AFC) şi osteoartropatia pulmonară hipertrofică (OAHP), acestea reprezentând o importantă cauză de morbiditate odată instalată $(13,14)$.

Artropatia din FC (AFC) - cea mai frecventă formă de artrită din FC, se manifestă clinic ca o mono- sau o poliartrită recurentă, asimetrică, care afectează în special genunchii (3). Prevalența AFC este estimată a fi între $2-8,5 \%$, cu o vârstă medie la instalare de aproximativ 13,6 ani, însă aceasta ar putea fi supraestimată întrucât există posibilitatea existenței unor cazuri la care este prezentă, dar nu a fost diagnosticată de-a lungul mai multor ani (6). $\mathrm{Nu}$ există o definiție formală a artritei din FC, dar ea se manifestă printr-o serie de simptome distincte precum: episoade recurente de durere şi tumefacție articulară, predominantă la nivelul articulațiilor genunchilor şi gleznelor, sensibilitate şi limitarea mişcărilor care sunt dizabilitante pentru bolnav. Durerea se dezvoltă în decursul a 12-24 ore şi durează între 5-7 zile, iar simptomele pot dispărea complet între acutizări (8).

Osteoartropatia hipertrofică pulmonară (OAHP) sau osteoartropatia Bamberger-Marie este mai puțin frecventă decât AFC, având o prevalență între $2-7 \%$, cu afectarea predominantă a sexului masculine (12). Tabloul clinic al OAHP cuprinde: hipocratismul digital (deformare în, „degete de toboşar"), manifestări osoase şi articulare şi manifestări cutanate $(15,22)$.

În studiul nostru, prevalența manifestărilor articulare a fost de $16,27 \%$. Boala a fost mai frecventă la sexul masculin (67\%), rezultatele obținute confirmând datele din literatură. Însă în literatura medicală de specialitate sexul masculin este considerat un factor de prognostic mai favorabil decât sexul feminin (19). 
Diferite studii susțin că bolnavii cu FC au un risc crescut de afectare a balanței calciului care, la rândul ei, afectează sănătatea osoasă, fapt confirmat şi de prezentul studiu (34\%) (1). Pentru creşterea absorbției calciului, aportul de calciu recomandat variază între $500 \mathrm{mg} / \mathrm{zi}$ pentru bolnavii cu vârsta 1-3 ani, $800 \mathrm{mg} /$ zi pentru copiii cu vârsta între 4-8 ani şi $1.300 \mathrm{mg} /$ zi pentru cei între 9-18 ani $(7,9)$.

Dozarea concentrațiilor de vitamina D şi de calciu se recomandă să fie efectuată cel puțin o dată pe an, ideal la sfârşitul iernii, întrucât valorile vitaminei D variază în funcție de anotimp $(20,11)$. Dacă acest lucru nu este posibil, se recomandă ca valorile obtinute să fie interpretate în contextul anotimpului din momentul determinării, gradului de expunere la soare a pacientului şi utilizării produselor topice cu factor de protectie UV (10).

Radiografia a avut un rol important în evaluarea afectării osteoarticulare întrucât este cunoscut faptul că semnele radiologice apar precoce, sunt prezente în stadiul în care semnele clinice sunt rare sau absente şi sunt considerate patognomonice (21).

Exacerbările infecțiilor pulmonare trebuie tratate prompt pentru a minimaliza efectele adverse ale inflamației asupra osului.

\section{CONCLUZII}

Tratamentul cu vitamina D, calciu şi suplimente cu multiminerale asociat cu regim igieno-dietetic corespunzător şi tratamentul de fond al maladiei a contribuit semnificativ în unele cazuri la îmbunătățirea stării de sănătate, determinând ameliorarea suferinței osteoarticulare şi a calității vieții.

Totodată, în unele cazuri lipsa complianței la tratament a pacienților sau familiilor acestora sau întreruperea schemei terapeutice, cât şi nerespectarea recomadărilor privind revenirea la control în vederea reevaluării clinico-biologice au contribuit semnificativ la instalarea precoce a complicaţiilor, îndeosebi a celor osteoarticulare (chiar de la vârsta de 6 ani).

Se impune ca toți pacienții cu FC să efectueze osteodensitometrie începând cu vârsta de 10 ani, o dată pe an sau la intervale de timp cuprinse între 1-3 ani, dar măcar o testare până la 18 ani (23). 